\title{
Samskipti án orða. Tengsl óyrtrar hegðunar yfir- manns og tilfinningalegrar líðan starfsfólks
}

\author{
Hildur Vilhelmsdóttir og Auður Hermannsdóttir ${ }^{1}$
}

\begin{abstract}
Ágrip
Líðan starfsfólks getur haft rekstrarleg áhrif á fyrirtæki og pví er mikilvægt fyrir stjórnendur að leggja áherslu á að starfsfólki líði vel. Yfirmenn geta aukið líkur á pví með pví að leggja áherslu á að eiga í góðum samskiptum við pað. Markmið rannsóknarinnar var að kanna tengsl á milli upplifunar af óyrtum samskiptum yfirmanns og tilfinningalegri líðan starfsfólks. Einblínt var á prjár gerðir tilfinningalegrar líðan sem eru mikilvægar pegar kemur að líðan starfsfólks í vinnu; tilfinningalegan stuðning, tilfinningalega vinnu og tilfinningalegt gildi. Í gegnum rafrænt hentugleikaúrtak fengust svör frá 802 einstaklingum á vinnumarkaði. Niðurstöðurnar sýndu að upplifun á óyrtum samskiptum yfirmanna hefur jákvæð tengsl við tilfinningalegan stuðning sem felst m.a. í pví að yfirmenn séu aðgengilegir og hlusti á starfsfólk. Upplifun á jákvæðum óyrtum samskiptum yfirmanna reyndist jafnframt draga úr skynjun starfsfólks á tilfinningalegri vinnu en slík vinna getur verið óæskileg og haft neikvæð áhrif á starfsfólk. Að auki sýndu niðurstöðurnar að skynjun starfsfólks á tilfinningalegu gildi er jákvæðara ef pað upplifir jákvæð óyrt samskipti frá yfirmanni sínum, en fyrri rannsóknir hafa sýnt að jákvætt tilfinningalegt gildi hefur jákvæð áhrif á starfsánægju og leiðir til jákvæðrar hegðunar inni á vinnistöðum. Miðað við niðurstöður rannsóknarinnar eru pað fyrst og fremst óyrt samskipti sem snúa að andlitstjáningu og líkamstjáningu sem skýra tilfinningalega líðan starfsfólks. Yfirmenn ættu pví að leggja áherslu á að halda augnsambandi við starfsfólk sitt pegar samskipti eiga sér stað og sýna jákvæð svipbrigði eins og bros. Jafnframt ætti að leggja áherslu á afslappaða en líflega líkamsstöðu, t.d. með pví að nota hendurnar pegar talað er. Rannsóknin styrkir fræðilegar undirstöður varðandi samskipti á vinnustað og veitir innsýn í lítið rannsakað viðfangsefni á sviði stjórnunar.
\end{abstract}

\begin{abstract}
Employees' well-being can influence companies' perfomance and therefore it is important for managers to do what they can so their employees are feeling well at work. Supervisors can increase the likelihood of their employees well-being by putting an emphasis on engaging in good communication with them. The purpose of the study was to investigate the relationship between how employees perceive their supervisors' nonverbal communication and the emotional well-being of employees. The focus was on three types of emotional well-being when it comes to
\end{abstract}

1 Hildur Vilhelmsdóttir er M.Sc. í mannauðsstjórnun. Netfang: hildurvil@gmail.com. Auður Hermannsdóttir er aðjúnkt við Viðskiptafræðideild Háskóla Islands. Netfang: audurhermannsdottir@hi.is.

This work is licensed under a Creative Commons Attribution 4.0 License.

DOI: https://doi.org/10.24122/tve.a.2019.16.2.5

(c) Tímarit um viðskipti og efnahagsmál 
employees well-being at work; emotional support, emotional work, and emotional valence. Through an online convenience sample answers were collected from 802 individuals in the labor market. The results show a positive relationship between how employees perceive their supervisors' nonverbal communication and percieved emotional support which involves supervisors being accessible and listen to their employees. Furthermore, if supervisors' nonverbal communication is perceived positive it diminishes employees emotional work, but emotional work can be disadvantageous and have negative effect on employees. Additionally, the results show that employees emotional valence is higer if they perceive their supervisors' nonverbal communication as positive, but previous studies have shown that emotional valence has a positive effect on job satisfaction and positivly effects behaviour within the workplace. According to the findings, it is first and foremost nonverbal communication related to bodily and facial expression that explains employees emotional well-being. Emphasis should therefore be put on keeping eye contact and on showing positive facial expression like smiling when communicating with employees. Likewise, supervisors should pay attention to their body position and try to be relaxed but spirited, for example by using their hands and arms to gesture while talking to others. The study offers an empirical contribution to strenghten the theoretical foundation regarding communication in the workplace and offers an insight into a field of mangement that has not been empirically studied to much extend.

JEL flokkun: M12, M54, D9

Lykilorð: Óyrt samskipti, starfsfólk tilfinningaleg líðan, tilfinningalegur stuðningur, tilfinningaleg vinna, tilfinningalegt gildi.

Keywords: Nonverbal communication, employees, emotional well-being, emotional support, emotional work, emotional valence.

\section{Communicating without words. The relationship between supervisors' nonverbal communication and employees' emotional well-being}

\section{Inngangur}

Раð eru ekki bara persónulegir hagsmunir starfsfólks að peim líði vel í vinnunni heldur getur líðan peirra beinlínis haft rekstrarleg áhrif á fyrirtæki. Starfsfólk sem líður vel í vinnunni sýnir betri afköst, minni streitu, er ólíklegra til að verða fyrir kulnun og tekur færri veikindadaga heldur en pað starfsfólk sem ekki líður vel, auk pess sem vellíðan starfsfólks dregur úr starfsmannaveltu (Decker og Borgen, 1993; Landy og Conte, 2013). раð er pví ljóst að pað eru hagsmunir fyrirtækja að starfsfólki peirra líði vel og pví ætti vellíðan að vera áhersluatriði stjórnenda.

Líðan starfsfólks getur í grófum dráttum annars vegar tengst líkamlegri heilsu og hins vegar andlegri heilsu, en hvort um sig getur falið í sér fjölda undirpátta (sjá t.d. Arnold, Turner, Barling, Kelloway og McKee, 2007; Grebner, Semmer og Elfering, 2005; Keyes, Shmothkin og Ryff, 2002; Schimmack, Radhakrishnan, Oishi, Dzokoto og Ahadi, 2002). Einn páttur sálfræðilegrar heilsu er tilfinningaleg líðan (emotional well-being) starfsfólks. Slík líðan vísar til tilfinningalegra viðbragða við aðstæðum í vinnuumhverfinu (Mottet, Frymier og Beebe, 2006; Parkinson, Totterdell, Briner og Reynolds, 1996), til dæmis upplifun á stuðningi frá yfirmanni (Beehr o.fl., 2003; Jia o.fl., 2017; Miceli, 2009) og mat á bæði vinnuumhverfinu í heild eða einstaklingum innan pess (Nixon, 2009).

Samskipti á vinnustaðnum er einn af peim grundvallarpáttum sem hafa áhrif á hvernig fólki líður í vinnunni, bæði samskipti starfsfólks í milli en ekki síður samskipti starfsfólks við yfirmann sinn (Nohe, Michaelis, Menges, Zhang og Sonntag, 2013; Yukl, 2002). Samskipti fela í grunninn í sér að skilaboð eru mótuð af sendanda og í kjölfarið send til 
móttakanda sem túlkar pau, en pessi skilaboð geta bæði verið mótuð með orðum en geta jafnframt verið án orða (Gillard og Johansen, 2004), p.e.a.s. skilaboðin geta ýmist verið yrt eða óyrt.

Pó svo að rannsóknir hafa sýnt hversu veigamikill páttur óyrt samskipti eru í daglegu lífi er skortur á slíkum rannsóknum í tengslum við vinnuumhverfið í heild (Bonaccio, O'Reilly, O'Sullivan og Chiocchio, 2016; Darioly og Schmidt, 2014; Fuller o.fl., 2011; Gkorezis, Bellou og Skemperis, 2015; Jia, Cheng og Hale, 2017). Aðeins nokkrar rannsóknir hafa snúið að viðhorfi starfsmanna í tengslum við óyrta hegðun yfirmanns (Teven, 2007) en par má nefna, ánægju með yfirmann (Riggio, Salinas, Riggio og Cole, 2003), upplifun á frammistöðu yfirmanns (Riggio o.fl., 2003) og áhrif töfrandi forystu yfirmanns (Awamleh og Gardner, 1999; Gardner, 2003). Í nýbirtri rannsókn Jia o.fl. (2017) komu fram sterk tengsl milli óyrtra samskipta yfirmanns og tilfinningalegrar líðan starfsfólk. Í ljósi pess hversu fáar rannsóknir hafa verið birtar sem snúa að óyrtri hegðun yfirmanna og í ljósi vísindalegs mikilvægis pess að endurtaka rannsóknir til að auka alhæfingargildi niðurstaðna peirra og styrkja fræðilegar undirstöður er pörf á fleiri rannsóknum á viðfangsefninu. Markmið rannsóknarinnar er að kanna tengsl milli upplifunar á óyrtum samskiptum yfirmanns og tilfinningalegrar líðan starfsfólk. Rannsókninni svipar pví að miklu leiti til rannsóknar Jia o.fl. (2017) en pó er í pessari rannsókn farið dýpra í skoðun á tengslum við tilfinningalega líðan starfsfókls. Í rannsókn Jia o.fl. (2017) voru tvær víddir tilfinningalegrar líðan skoðaðar; tilfinningalegur stuðningur og tilfinningaleg vinna. Í pessari rannsókn er hins vegar farið dýpra í tilfinningalega líðan með pví að bæta við priðju víddinni; tilfinningalegu gildi.

Rannsókninni er ætlað að styrkja fræðilegar undirstöður varðandi samskipti á vinnustað og veita innsýn í lítið rannsakað viðfangsefni á sviði stjórnunar. Auk hins fræðilega framlags er hagnýtt framlag rannsóknarinnar mikilvægt. Rannsóknin gefur stjórnendum upplýsingar um hvort og hversu mikið óyrt samskipti peirra skýra af tilfinningalegri líðan starfsmanna. Í ljósi pess að líðan starfsfólks getur haft bein áhrif á rekstrarlegan árangur fyrirtækja er vitneskja um með hvaða hætti sé hægt að aðlaga hegðun til að auka líkur á að hafa jákvæð áhrif á líðan gagnleg stjórnendum.

\section{2 Óyrt samskipti yfirmanna}

Samskipti eru órjúfanlegur hluti af bví að vera mannlegur par sem við sendum stöðugt frá okkur bein eða óbein skilaboð til annars fólks, ýmist meðvitað eða ómeðvitað (Moss, 2008). Ef starfsfólk upplifir yfirmann sinn sýna jákvæða hegðun í samskiptum telja peir sig almennt við betri andlega heilsu (Gilbreath og Benson, 2004) á meðan neikvæð hegðun yfirmanna getur leitt til neikvæðrar upplifunar og jafnvel örmögnunar starfsfólks (Fitness, 2000; Fox og Stallworth, 2005; Frone, 2000; Glomb, 2002; LeBlanc og Kelloway, 2002) ásamt pví að hafa neikvæð áhrif á frammistöðu peirra (Rayner, Hoel og Cooper, 2002; Robertson og Flint-Taylor, 2008)

Óyrt samskipti eru öll pau skilaboð sem við sendum frá okkur fyrir utan tungumálið sjálft, t.d. í gegnum svipbrigði, augnsamband, raddblæ, tónhæð, handahreyfingar og snertingu (Ambady og Weisbuch, 2010; Burgoon, Guerrero, og Manusov, 2011), en talið er að slík samskipti séu allt að 90\% af öllum samskiptum (Birdwhistell,1970). Pegar um óyrt samskipti er að ræða er ekki endilega til staðar ætlun um að senda ákveðin skilaboð (Burgoon o.fl., 2011) heldur er stór hluti óyrtrar hegðunar ómeðvituð (Dimberg, Thunberg og Elmehed, 2000) sem gerir раð аð verkum að erfitt getur verið að stjórna henni (DePaulo 1992; Ekman og Friesen, 1969, 1974). Að pví sögðu er ekki par með sagt að öll óyrt hegðun sé ómeðvituð og óstjórnanleg. Hægt er að stjórna ákveðinni líkamshegðun eða svipbrigðum meðvitað, líkt og brosi i ákveðinn tíma eða í ákveðnum aðstæðum en sú stjórnun er ekki stöðug yfir tíma né aðstæður (Porter, Brinke og Wallace, 2012).

Hið óyrta leikur lykilhlutverk í félagslegum samskiptum (Burgoon, Buller og Woodall, 1996) og er talið að fólk reiði sig almennt frekar á pað sem pað sér heldur en talað mál 
pegar pað myndar sér skoðanir á öđru fólki (Burgoon, Blair og Strom, 2008). Darioly og Schmid (2014) staðhæfa að óyrt samskipti séu mikilvægari heldur en yrt mál pegar kemur að starfi stjórnandans. Í gegnum ýmiss konar óyrt samskipti getur stjórnandi pannig haft áhrif á starfsfólk. Til að mynda getur óyrt hegðun líkt og nánd og viðeigandi snerting styrkt tengsl yfirmanns við undirmenn sína (Bonaccio o.fl., 2016) og haft jákvæð áhrif á upplifaðan stuðning peirra (Fuller o.fl., 2011; Marler, Cox, Simmering, Bennett og Fuller, 2011). Einnig getur slík nánd haft jákvæð áhrif á starfsánægju (Richmond og McCroskey, 2000) og viðhorf undirmanna til síns yfirmanns (Hinkle, 2001; Teven, 2007, 2010).

\section{Tilfinningaleg líðan starfsfólks}

Tilfinningar eru viðbragð við aðstæðum eða áreiti í umhverfinu, til að mynda hegðun annarra (Mottet o.fl., 2006; Parkinson o.fl., 1996) og snúa fyrst og fremst að upplifun á tilteknum aðstæðum eða áreiti (Andersen, 1979). Раð er pví upplifunin á aðstæðunum eða áreitinu sem kallar fram tilfinningar hjá einstaklingum og peirra tilfinningalegu líðan. Pegar um tilfinningalega líðan starfsfólk er að ræða snýr slík líðan fyrst og fremst að tilfinningalegum viðbrögðum við aðstæðum í vinnuumhverfinu (Mottet, Frymier og Beebe, 2006; Parkinson o.fl., 1996). Slíkar aðstæður geta til dæmis snúið að upplifun á stuðningi frá yfirmanni (Beehr o.fl., 2003; Jia o.fl., 2017; Miceli, 2009) eða heildrænu mati á vinnuumhverfinu eða einstaklingum innan pess (Nixon, 2009). Рað eru pví ýmsir pættir sem geta fallið undir tilfinningalega líðan starfsfólks en í pessari rannsókn er einblínt á prjár gerðir; tilfinningalegan stuðning (e. emotional support), tilfinningalega vinnu (e. emotional work) og tilfinningalegt gildi (e. emotional valence).

Tilfinningalegur stuðningur felur í sér að einstaklingi er sýnd væntumpykja, áhugi, skilningur og samkennd (Miller, 2009). Slíkur stuðningur hefur oftast verið tengdur við fjölskyldumeðlimi eða nána vini (Miller, 2009), hins vegar hafa rannsóknir sýnt fram á mikilvægi slíks stuðnings innan vinnustaða (Colquitt og LePine, 2000; Jia og Soham, 2012), sér í lagi frá valdameiri einstaklingum líkt og yfirmönnum (Beehr o.fl., 2003; Jia o.fl., 2017; Miceli, 2009). Tilfinningalegur stuðningur frá yfirmanni snýr að pví að hann sé aðgengilegur, hlusti, gefi ráð og veiti almennan stuðning, hvort sem pað er varðandi málefni sem eru með beinum eða óbeinum hætti tengd vinnunni (Miceli, 2009). Stuðningurinn getur pví falist í orðum en miðað við niðurstöður Jia o.fl. (2017) geta yfirmenn jafnframt veitt stuðning í gegnum óyrt samskipti. Stuðningur frá yfirmanni hefur áhrif á upplifun starfsfólks á pví hvort skipulagsheildin sem pað starfar hjá metur framlag pess og er annt um velferð pess ásamt pví að hafa víðtæk áhrif á frammistöðu, almenna líðan, starfsánægju og streitu (Beehr o.fl., 2003; Galletta o.fl., 2011; Gibson o.fl., 2009; Jenkins og Elliott, 2004; Nagami o.fl., 2010; Rhoades og Eisenberger, 2002; Selvarajan o.fl., 2013; Willemse, Jonge, Smit, Depla og Pot, 2012). Lítill stuðningur frá yfirmanni getur aftur á móti leitt til andlegra heilsufarsvandamála eins og punglyndis (Rugulies, Bültmann, Aust og Burr, 2006), sálræns álags og kvíða (Beehr o.fl.,2003; Sinokki o.fl., 2009) og kulnunar (Gibson o.fl., 2009). Að auki er lítill stuðningur frá yfirmanni talinn auka starfsmannaveltu (Galletta o.fl., 2011; Willemse o.fl., 2012) og getur par með verið kostnaðarsamur fyrir fyrirtæki. Í ljósi framangreindrar umfjöllunar er tilgáta 1 sett fram:

T1: Jákvæð tengsl eru á milli upplifunar á óyrtum samskiptum yfirmanns og skynjunar starfsfólks á tilfinningalegum stuðningi

Tilfinningaleg vinna snýr að pví að stjórna meðvitað peim tilfinningum sem sýndar eru innan vinnustaðar (Buzzanell og Turner, 2003; Kruml og Geddes, 2000; Miller, 2007) og getur slíkt krafist mikillar andlegrar orku (Grandey, 2000; Kruml og Geddes, 2000). Með tilfinningalegri vinnu getur starfsfólk ýmist bælt niður eða pvingað fram ákveðna hegðun og tilfinningar (Buzzanell og Turner, 2003; Kruml og Geddes, 2000; Miller, 2007), t.d. fé- 
lagslega sampykkta hegðun líkt og bros pegar slík tilfinning er ekki til staðar (Grandey, 2000; Pugh, Groth, og Hennig-Thurau, 2011). Ef mikil tilfinningaleg vinna á sér stað í daglegum samskiptum innan vinnustaðar getur slíkt verið streituvaldandi og aukið líkur á óánægju, andlegu álagi og kulnun (Kruml og Geddes, 2000; Jia o.fl., 2017; Nixon, 2009; Pugh o.fl., 2011; Zapf, 2002). Slíkt getur einnig leitt til neikvæðra tilfinninga gagnvart vinnustaðnum (Nixon, 2009) og jafnvel leitt til pess að starfsfólk ákveði að yfirgefa vinnustaðinn (Grandey, 2000; Jia o.fl.. 2017; Pugh o.fl., 2011). Í gegnum jákvæð óyrt samskipti virðast yfirmenn pó geta dregið úr upplifun starfsfólks á tilfinningalegri vinnu (Jia o.fl., 2017). Pví er tilgáta 2 sett fram:

T2: Neikvæð tengsl eru á milli upplifunar á óyrtum samskiptum yfirmanns og skynjunar starfsfólks á tilfinningalegri vinnu

Tilfinningalegt gildi er jákvætt eða neikvætt mat einstaklings á umhverfi sínu eða einstaklingum innan pess (Nixon, 2009). Eðli máls samkvæmt er starfsánægja fólks almennt meiri ef tilfinningalegt gildi er jákvætt og pví er tilfinningalegt gildi talið hafa áhrif á bæði hegðun og viðhorf fólks til vinnunar (Brockner og Higgins, 2001). Hegðun annarra í tilteknu umhverfi getur haft áhrif á tilfinningalegt gildi til umhverfisins sjálfs. Rannsókn Teven (2007) sýndi að ef yfirmaður sýnir jákvæða óyrta hegðun í samskiptum pá leiði pað til jákvæðrar upplifunar starfsfólks af vinnunni og viðkomandi yfirmanni. Í svipuðum dúr sýndu niðurstöður Titsworth, Mckenna, Mazer og Quinlan (2013) að hegðun kennara geti leitt til pess að nemendur upplifi neikvætt tilfinningalegt gildi gagnvart námi. Gera má ráð fyrir að samband kennara og nemenda annars vegar og samband yfirmanns og undirmanna hins vegar geti að mörgu leiti verið sambærilegt að pví leiti að ákveðið valdaójafnvægi er oft til staðar par sem kennarar og yfirmenn eru í valdameiri stöðu gagnvart nemendum og undimönnum. Í ljósi framangreindrar umræðu um niðurstöður fyrri rannsókna má leiða líkur að pví að hegðun yfirmanns geti leitt til neikvæðs tilfinningalegs gildis starfsfólks gagnvart vinnunni. I ljósi framangreinds er tilgáta 3 sett fram:

T3: Jákvæð tengsl eru á milli upplifunar á óyrtum samskiptum yfirmanns og skynjunar starfsfólks á tilfinningalegu gildi

\section{4 Аðferð}

Markmið rannsóknarinnar var að kanna hvort tengsl væru á milli upplifunar starfsfólks á óyrtum samskiptum yfirmanns og priggja tegunda tilfinningalegrar líðan, p.e. tilfinningalegum stuðningi, tilfinningalegri vinnu og tilfinningalegu gildi. Settar voru fram prjár tilgátur sem snúa að pessum tengslum. Fjallað verður um pátttakendur rannsóknarinnar, mælitækið ásamt pví að framkvæmdinni verður lýst.

\subsection{Pátttakendur}

Notast var við rafrænt hentugleikaúrtak og lögð áhersla á að ná til sem fjölbreyttasta hóps pátttakenda. Alls tóku 802 einstaklingar pátt í rannsókninni. Töluverður meirihluti pátttakenda voru konur eða 70,9\%, hins vegar var aldursdreifing nokkuð góð. Kyn yfirmanna pátttakanda skiptist nokkuð jafnt, karlkyns yfirmenn voru 46,9\% og kvenkyns yfirmenn $53,1 \%$. Frekari upplýsingar um pátttakendur er að finna í töflu 1. 
Tafla 1. Aldur, menntun og mánaðartekjur pátttakenda.

\begin{tabular}{lrlrlr}
\hline \multicolumn{1}{c}{ Aldur } & \multicolumn{2}{c}{ Menntun } & \multicolumn{2}{c}{ Mánaðartekjur } \\
\hline 25 ára og yngri & $7,8 \%$ & Grunnskólapróf & $10,5 \%$ & 200.000 eða lægri & $5,7 \%$ \\
26 til 30 ára & $22,7 \%$ & Stúdentspróf & $12,9 \%$ & 200.001 til 400.000 & $14,3 \%$ \\
31 til 35 ára & $15,3 \%$ & Iðnpróf & $9,0 \%$ & 400.001 til 600.000 & $35,2 \%$ \\
36 til 40 ára & $12,6 \%$ & Háskólapróf á grunnstigi & $32,9 \%$ & 600.001 til 800.000 & $27,3 \%$ \\
41 til 45 ára & $10,0 \%$ & Háskólapróf á framhaldsstigi & $32,4 \%$ & 800.001 til 1.000.000 & $11,6 \%$ \\
46 til 50 ára & $11,1 \%$ & Annað & $2,3 \%$ & 1.000 .001 eða hærri & $5,9 \%$ \\
51 til 60 ára & $15,0 \%$ & & & & \\
61 árs og eldri & $5,5 \%$ & & & & \\
\hline
\end{tabular}

\subsection{Mælitæki}

Mælitækið skiptist í tvo hluta. Í fyrri hlutanum var upplifun á óyrtri hegðun yfirmanns mæld og í seinni hlutanum var tilfinningaleg líðan starfsmannsins mæld. Í upphafi birtust pátttakendum pó tvær síuspurningar. Annars vegar spurning sem snéri að pví hvort viðkomandi væri í starfi eða ekki og hins vegar spurning sem snéri að pví hvort viðkomandi væri með yfirmann. Í ljósi markmiða rannsóknarinnar var nauðsynlegt að einstaklingar svöruðu báðum spurningum játandi til að geta tekið pátt.

Upplifun á óyrtri hegðu yfirmanns var mæld með kvarðanum Nonverbal Immediacy Scale (NIS), próuðum af Richmond, McCroskey og Johnson (2003). Áreiðanleiki eldri kvarða sem notaðir hafa verið við mælingar á óyrtri hegðun var talinn of lítill sem var hvatinn á bak við að Richmond o.fl. (2003) próuðu NIS.

Kvarðinn sem samanstendur af 26 atriðum; 13 jákvæðum fullyrðingum og 13 neikvæðum fullyrðingum tekur til ýmissa pátta sem fyrri rannsóknir hafa sýnt að séu mikilvægir pegar kemur að óytri hegðun á vinnustöðum, p.e. líkamlegri tjáningu (7 atriði), nánd (8 atriði), raddblæs (4 atriði) og andlitstjáningu (7 atriði). Í töflu 2 má sjá atriði kvarðans en tekið skal fram að röð atriða í töflunni er ekki sú sama og birtist pátttakendum heldur var lögð áhersla á að dreifa atriðum sem snéru að sambærilegum páttum til að draga úr líkum á að svör pátttakenda yrðu fyrir of miklum áhrifum af nærstandandi atriðum í mælitækinu. Pátttakendur tóku afstöðu til fullyrðinganna á 5 punkta Likert kvarða par sem allir svarkostir voru merktir með orðgildum til að auka áreiðanleika. Svarkostirnir voru (1) mjög sjaldan, (2) sjaldan, (3) stundum, (4) oft og (5) mjög oft.

Við mat á tilfinningalegri líðan starfsmanna var notast við kvarðann Classroom Emotional Scale (CES) próuðum af Titsworth, Quinlan og Mazer (2010), en einu atriði bætt við kvarðann til að ná betur utan um víddina tilfinningalegt gildi. Auk tilfinningalegs gildis (3 atriði), mælir kvarðinn tilfinningalegan stuðning (8 atriði) og tilfinningalega vinnu (4 atriði). Pátttakendur tóku afstöðu til fullyrðinganna 15 á 5 punkta Likert kvarða par sem allir svarkostir voru merktir með orðgildum til að auka áreiðanleika. Svarkostirnir voru (1) mjög ósammála, (2) ósammála, (3) hvorki né, (4) sammála og (5) mjög sammála. Í töflu 3 má sjá atriði kvarðans en líkt og í tilfelli NIS í töflu 1 er röð atriða í töflunni ekki sú sama og birtist pátttakendum heldur var lögð áhersla á að dreifa atriðum sem snéru að sambærilegum páttum til að draga úr líkum á að svör pátttakenda yrðu fyrir of miklum áhrifum vegna nástöðu annarra atriða.

Báðir kvarðarnir voru pýddir af höfundum yfir á íslensku. Sex einstaklingar voru fengnir til að forprófa mælitækið með tilliti til orðalags og skilnings. Smávægilegar athugsemdir komu fram í forprófun sem tekið var tillit til. 


\subsection{Framkvæmd}

Spurningalistanum var dreift rafrænt á samfélagsmiðlinum Facebook og var lögð áhersla á að ná til fjölbeytts hóps pátttakenda. Samfélagsmiðillinn Facebook er í síauknum mæli notaður við gagnaöflun, m.a. vegna vinsælda og mikillar útbreiðslu miðilsins. Rannsóknir hafa leitt í ljós að notkun miðilsins við gagnaöflun sé ákjósanleg og jafnvel fýsilegri en aðrar aðferðir við öflun hentugleikaúrtaks (Casler, Bickel og Hackett, 2013; Rife, Cate, Kosinski og Stillwell, 2016; Thorntorn o.fl., 2016).

Áður en pátttakendur gátu hafist handa við að svara könnuninni birtust peim upplýsingar um markmið rannsóknarinnar ásamt pví að peir voru upplýstir um að svör yrðu ekki rakin til peirra.

\section{Niðurstöður}

Við greiningu á niðurstöðum rannsóknarinnar verður byrjað á að greina frá lýsandi niðurstöðum sem snúa að upplifun á óyrtri hegðun yfirmanns. Í kjölfarið verður greint frá lýsandi niðurstöðum sem snúa að tilfinningalegri líðan. Að lokum verða tilgátur rannsóknarinnar kannaðar par sem tengsl á milli upplifunar á óyrtri hegðun yfirmanns og tilfinningalegri líðan starfsfólks verða greind.

\subsection{Upplifun á óyrtri hegðun yfirmanns}

Í töflu 2 má sjá lýsandi tölfræði hvers atriðis sem notað var til að mæla upplifun á óytri hegðun yfirmanns. Í töflunni er atriðum kvarðans raðað saman eftir tegundum óyrtrar hegðunar. Áreiðanleiki páttanna fjögurra; líkamleg tjáning $(\alpha=, 712)$, nánd $(\alpha=, 705)$, raddblær $(\alpha=, 832)$ og andlitsjáning $(\alpha=, 828)$, mældum með Chronbach's Alpha $(\alpha)$ reyndist í öllum tilvikum ásættanlegur. Áreiðanleiki kvarðans í heild reyndis góður $(\alpha=, 903)$. Við sameiningu atriða hvers páttar var neikvætt orðuðu fullyrðingunum snúið við og eru pær stjörnumerktar í töflunni. Í töflu 2 er lýsandi tölfræði peirra atriða pó birt eins og hún var fyrir snúning. 
Tafla 2. Lýsandi niðurstöður um upplifun starfsfólks af óyrtri hegðun yfirmann

\begin{tabular}{|c|c|c|c|}
\hline & M & sf & $\mathrm{n}$ \\
\hline Líkamleg tjáning & 3,68 & 0,66 & 767 \\
\hline $\begin{array}{l}\text { Yfirmaður minn notar hendurnar til pess að leggja áherslu á orð sín á meðan hann/hún talar } \\
\text { við fólk }\end{array}$ & 2,89 & 1,18 & 801 \\
\hline $\begin{array}{l}\text { Yfirmaður minn notar hreyfingar til pess að leggja áherslu á orð sín pegar hann/hún talar við } \\
\text { fólk }\end{array}$ & 2,91 & 1,16 & 796 \\
\hline $\begin{array}{l}\text { Yfirmaður minn forðast að nota hreyfingar til pess að leggja áherslu á orð sín pegar hann/hún } \\
\text { talar við fólk* }\end{array}$ & 1,97 & 0,98 & 789 \\
\hline Yfirmaður minn er lífleg/ur pegar hann/hún talar við fólk & 3,82 & 1,08 & 786 \\
\hline Yfirmaður minn er stíf/stífur pegar hann/hún talar við fólk* & 1,97 & 1,07 & 791 \\
\hline Yfirmaður minn er með afslappaða líkamsstöðu á meðan hann/hún talar við fólk & 3,87 & 1,09 & 795 \\
\hline Yfirmaður minn er með spennta/stífa líkamsstöðu á meðan hann/hún talar við fólk* & 1,84 & 1,08 & 795 \\
\hline Nánd & 3,24 & 0,61 & 743 \\
\hline Yfirmaður minn snertir aðra á öxlina eða handlegginn á meðan hann/hún talar við viðkomandi & 1,71 & 1,01 & 798 \\
\hline Yfirmaður minn forðast að snerta fólk á meðan hann/hún talar við pað* & 2,97 & 1,31 & 779 \\
\hline Yfirmaður minn færir sig frá fólki pegar pað snertir hann/hana á meðan viðkomandi talar* & 1,61 & 0,91 & 783 \\
\hline Yfirmaður minn situr eða stendur nálægt fólki á meðan hann/hún talar við viðkomandi & 3,15 & 1,21 & 793 \\
\hline Yfirmaður minn færir sig nær fólki á meðan hann/hún talar við pað & 2,86 & 1,09 & 792 \\
\hline Yfirmaður minn hallar sér nær fólki sem hann/hún talar við & 2,67 & 1,06 & 787 \\
\hline Yfirmaður minn reynir að vera ekki mjög nálægt fólki pegar hann/hún talar við viðkomandi* & 2,18 & 1,01 & 786 \\
\hline Yfirmaður minn hallar sér frá fólki á meðan hann/hún talar við pað* & 1,82 & 0,93 & 789 \\
\hline Raddblær & 3,88 & 0,90 & 774 \\
\hline Yfirmaður minn notar einhæfan og daufan tón á meðan hann/hún talar við fólk* & 1,77 & 1,02 & 795 \\
\hline Rödd yfirmanns míns er einhæf og dauf pegar hann/hún talar við fólk* & 1,70 & 1,03 & 798 \\
\hline Yfirmaður minn notar fjölbreyttan talanda pegar hann/hún talar við fólk & 3,43 & 1,19 & 793 \\
\hline Yfirmaður minn notar fjölbreyttan raddblæ pegar hann/hún talar við fólk & 3,52 & 1,20 & 787 \\
\hline Andlitstjáning & 4,13 & 0,68 & 770 \\
\hline Yfirmaður minn lítur framhjá eða burtu frá fólki á meðan hann/hún talar við viðkomandi & 1,73 & 1,01 & 798 \\
\hline Yfirmaður minn forðast augnsamband á meðan hann/hún talar við fólk* & 1,57 & 0,94 & 796 \\
\hline Yfirmaður minn horfir beint á fólk á meðan hann/hún talar við pað & 4,01 & 0,89 & 795 \\
\hline Yfirmaður minn heldur augnsambandi við fólk á meðan hann/hún talar við pað & 4,01 & 0,94 & 784 \\
\hline Yfirmaður minn sýnir lítil sem engin svipbrigði pegar hann/hún talar við fólk* & 1,98 & 0,99 & 796 \\
\hline Yfirmaður minn grettir sig pegar hann/hún talar við fólk* & 1,70 & 0,99 & 799 \\
\hline Yfirmaður minn brosir pegar hann/hún talar við fólk & 3,83 & 1,03 & 785 \\
\hline
\end{tabular}

* Atriði snúið við pegar atriðin voru sameinuð í viðeigandi pátt

Við mat á styrkleika tengsla var horft til viðmiða Field (2005). Sterk jákvæð fylgni reyndist vera á milli upplifunar pátttakenda á páttum óyrtrar hegðunar yfirmanns. Ef upplifun á líkamlegri tjáningu var jákvæð, var upplifun á nánd nokkuð mikil, $r(728)=, 547 ; p<0,001$, ásamt pví að bæði raddblær, $r(751)=, 650 ; p<0,001$, og andlitstjáning, $r(748)=, 658 ; p<$ 0,001, voru metin á jákvæðan hátt. Ef nánd var metin mikil var jafnframt jákvæð upplifun á raddblæ, $r(727)=, 464 ; p<0,001$ og andlitstjáningu, $r(748)=, 658 ; p<0,001$. Einnig reyndist andlitstjáning vera metin á jákvæðan hátt ef raddblærinn var metinn jákvæður, $r(753)=$ ,672; $p<0,001$. 


\subsection{Tilfinningaleg líðan}

Í töflu 3 má sjá lýsandi tölfræði hvers atriðis sem notað var til að mæla tilfinningalega líðan. Áreiðanleiki páttanna priggja; tilfinningalegs stuðnings $(\alpha=, 911)$, tilfinningalegri vinnu $(\alpha=, 789)$ og tilfinningalegs gildis $(\alpha=, 846)$, mældum með Chronbach's Alpha $(\alpha)$, reyndist í öllum tilvikum ásættanlegur;. Tveimur atriðum sem tilheyra tilfinningalegum stuðningi var snúið við pegar atriðin voru sameinuð en í töflu 3 eru lýsandi niðurstöður peirra birtar fyrir snúning.

Tafla 3. Lýsandi niðurstöður um tilfinningalega líðan starfsfólks

\begin{tabular}{|c|c|c|c|}
\hline & $\mathbf{M}$ & sf & n \\
\hline Tilfinningalegur stuðningur & 3,72 & 0,92 & 783 \\
\hline Ég fæ pá andlegu hjálp og stuðning sem ég parf frá yfirmanni mínum & 3,54 & 1,21 & 798 \\
\hline Yfirmaður minn er reiðubúinn til pess að hjálpa mér að taka ákvarðanir tengdar vinnu & 4,01 & 1,05 & 796 \\
\hline Yfirmaður minn er reiðubúinn að ræða um tilfinningar mínar og líðan gagnvart vinnunni & 3,71 & 1,17 & 794 \\
\hline Ég get stólað á yfirmann minn pegar upp koma erfiðleikar í mínu persónulega lífi & 3,76 & 1,21 & 789 \\
\hline Ég get talað við yfirmann minn um mín persónulegu vandamál & 3,50 & 1,22 & 791 \\
\hline Yfirmaður minn er ekki móttækilegur fyrir áhyggjum mínum og líðan* & 2,25 & 1,21 & 793 \\
\hline Ég get treyst á yfirmann minn pegar eitthvað fer úrskeiðis í tengslum við vinnuna & 3,97 & 1,09 & 793 \\
\hline Ég get ekki talað um mín persónulegu vandamál við yfirmann minn* & 2,46 & 1,26 & 792 \\
\hline Tilfinningaleg vinna & 2,58 & 0,99 & 784 \\
\hline Að eiga samskipti við yfirmann minn krefst mikillar andlegrar orku & 2,44 & 1,28 & 795 \\
\hline Pegar ég tala við yfirmann minn verð ég að leyna tilfinningum mínum eða gera mér upp líðan & 2,09 & 1,16 & 793 \\
\hline Ég vildi að ég gæti tjáð líðan mína betur við yfirmann minn & 2,60 & 1,24 & 791 \\
\hline Að vera á pessum vinnustað krefst mikillar andlegrar orku & 3,17 & 1,38 & 792 \\
\hline Tilfinningalegt gildi & 3,98 & 0,91 & 780 \\
\hline Á heildina litið myndi ég lýsa tilfinningum mínum gagnvart yfirmanni mínum sem jákvæðum & 3,94 & 1,14 & 790 \\
\hline Á heildina litið myndi ég lýsa tilfinningum mínum gagnvart vinnustaðnum sem jákvæðum & 3,99 & 0,96 & 793 \\
\hline Á heildina litið líður mér vel í vinnunni & 4,00 & 1,02 & 791 \\
\hline
\end{tabular}

*Atriði snúið við pegar atriðin voru sameinuð í viðeigandi pátt

Sterk fylgni reyndist vera á milli allra pátta tilfinningalegrar líðan. Pátttakendur sem upplifa tilfinningalegan stuðning eru afar ólíklegir til að upplifa tilfinningalega vinnu, $r(775)$ $=-, 726 ; p<0,001$, en eru mjög líklegir til að upplifa tilfinningalegt gildi, $r(769)=, 747 ; p<$ 0,001. Að sama skapi eru peir sem upplifa mikla tilfinningalega vinnu ólíklegir til að upplifa tilfinningalegt gildi, $r(769)=-, 655 ; p<0,001$.

\subsection{Tengsl upplifunar á óyrtri hegðun yfirmanns og tilfinningalegri líðan starfsfólks}

Prjár tilgátur voru settar fram sem snéru að pví að upplifun starfsfólks af óyrtum samskiptum yfirmanns hefðu jákvæð tengsl við tilfinningalegan stuðning (tilgáta 1), neikvæð tengsl við tilfinningalega vinnu (tilgáta 2) og jákvæð tengsl við tilfinningalegt gildi (tilgáta 3). Niðurstöðurnar sýndu sterk tengsl á milli óyrtrar hegðunar í heild og allra priggja pátta tilfinningalegrar líðan (sjá töflu 4). Eftir pví sem upplifun á óyrtri hegðun yfirmanns er jákvæðari, pví meiri tilfinningalegan stuðning, $r(691)=, 603 ; p<0,001$, og hærra tilfinningalegt gildi, $r(686)=, 519 ; p<0,001$, upplifir starfsfólk. Að sama skapi dregur jákvæð upplifun á óyrtri hegðun yfirmanns úr tilfinningalegri vinnu starfsfólks, $r(691)=-, 490 ; p<0,001$. Niðurstöðurnar styðja pví allar tilgáturnar sem settar voru fram. 
Tafla 4. Tengsl milli allra mældra pátta

\begin{tabular}{lccccccc}
\hline Pættir & $\mathbf{1}$ & $\mathbf{2}$ & $\mathbf{3}$ & $\mathbf{4}$ & $\mathbf{5}$ & $\mathbf{6}$ & $\mathbf{7}$ \\
\hline 1. Líkamleg tjáning & 1 & & & & & & \\
2. Nánd &, $547^{* * *}$ & 1 & & & & & \\
3. Raddblær &, $650^{* * *}$ &, $464^{* * *}$ & 1 & & & & \\
4. Andlitstjáning &, $658^{* * *}$ &, $494^{* * *}$ &, $672^{* * *}$ & 1 & & & \\
5. Tilfinningalegur stuðningur &, $558^{* * *}$ &, $330^{* * *}$ &, $498^{* * *}$ &, $619^{* * *}$ & 1 & & \\
6. Tilfinningaleg vinna &,$- 441^{* * *}$ &,$- 236^{* * *}$ &,$- 409^{* * *}$ &,$- 564^{* * *}$ &,$- 726^{* * *}$ & 1 & \\
7. Tilfinningalegt gildi &, $464^{* * *}$ &, $270^{* * *}$ &, $400^{* * *}$ &, $560^{* * *}$ &, $747^{* * *}$ &,$- 655^{* * *}$ & 1 \\
\hline$* * * p<0,001$ & & & & & & &
\end{tabular}

Til að kanna pessi sambönd betur og fá pannig nákvæmari upplýsingar um hvers konar óyrt hegðun er líkleg til að skýra tilfinningalega líðan starfsfólks voru framkvæmdar margvíðar aðhvarfsgreiningar par sem óháðu breyturnar voru fjórir pættir óyrtrar hegðunar, p.e. líkamleg tjáning, nánd, raddblær og andlitstjáning. Forsendur aðhvarfsgreininganna voru kannaðar. Hvorki reyndist vera sjálffylgni né marglínuleiki í gögnunum, frávikin í fylgibreytunum voru normaldreifð og punktaritin sýndu enga misdreifni. Pví stóðust forsendur aðhvarfsgreiningar í öllum tilvikum. Við framkvæmd aðhvarfsgreininganna var leiðrétt fyrir kyni pátttakenda, aldri peirra, menntun og tekjum ásamt kyni yfirmanns.

Upplifun á óyrtri hegðun yfirmanns skýrði í öllum tilvikum nokkurn hluta tilfinningalegrar líðan eða frá $\mathrm{R}^{2}=, 328$ upp í $\mathrm{R}^{2}=, 417$ og voru heildaráhrif líkananna í öllum tilvikum marktæk, $p<0,001$ (sjá töflu 4).

Tafla 5. Niðurstöður aðhvarfsgreininga

\begin{tabular}{lccccc}
\hline & Líkamleg tjáning & Nánd & Raddblær & Andlitstjáning & \\
\hline & $\beta$ & $\beta$ & $\beta$ & $\beta$ & R2 \\
Tilfinningalegur stuðningur &, $250^{* * *}$ &,- 048 &, 073 &, $420^{* * *}$ &, 417 \\
Tilfinningaleg vinna &,$- 123^{* *}$ &, 063 &,- 036 &,$- 487^{* * *}$ &, 328 \\
Tilfinningalegt gildi &,$- 190^{* * *}$ &,- 053 &, 006 &, $464^{* * *}$ &, 352 \\
\hline
\end{tabular}

${ }^{*} \mathrm{p}<0,05 ;{ }^{* *} \mathrm{p}<0,01 ; * * * \mathrm{p}<0,001$

Upplifun af óyrtri hegðun yfirmanns í gegnum andlitstjáningu reyndist í öllum tilvikum hafa sterkastan skýringarmátt á tilfinningalega líðan pátttakenda. Líkamleg tjáning reyndist jafnframt skýra alla prjá pætti tilfinningalegrar líðan en hvorki nánd né raddblær reyndust skýra tilfinningalega líðan starfsfólks.

\section{Umræða}

Раð eru rekstrarlegir hagsmunir fólgnir í pví fyrir fyrirtæki að starfsfólki líði vel í vinnunni. Afköst verða meiri, pað dregur úr streitu, ólíklegra er að fólk verði fyrir kulnun í starfi auk pess sem vellíðan starfsfólks dregur úr starfsmannaveltu (Decker og Borgen, 1993; Landy og Conte, 2013). Yfirmenn geta aukið líkur á að starfsfólki líði vel með pví að leggja áherslu á að eiga í góðum samskiptum við pað, en par sem aðeins í kringum 10\% samskipta felast í pví sem sagt er (Birdwhistell,1970) skiptir máli að huga að hinu ósagða, p.e. óyrtum samskiptum, og mögulegum áhrifum pess á líðan starfsfólks.

Markmið rannsóknarinnar var að kanna tengsl upplifunar á óyrtum samskiptum yfirmanna og tilfinningalegri líðan starfsfólks. Settar voru fram prjár tilgátur sem snúa að pessum tengslum og voru pær allar studdar. Niðurstöðurnar sýndu að upplifun á óyrtum samskiptum yfirmanna hefur jákvæð tengsl við tilfinningalegan stuðning og er pað í samræmi við niðurstöður Jia o.fl. (2017). Tilfinningalegur stuðningur frá yfirmönnum felst m.a. í pví að peir séu aðgengilegir, hlusti á starfsfólk og gefi pví ráđ, hvort sem pað er 
varðandi málefni sem eru með beinum eða óbeinum hætti tengd vinnunni (Miceli, 2009). Slíkur stuðningur er mikilvægur innan fyrirtækja (Colquitt og LePine, 2000; Jia og Soham, 2012) og hefur víðtæk áhrif á frammistöðu starfsfólks (Beehr o.fl., 2003; Galletta o.fl., 2011; Gibson o.fl., 2009; Jenkins og Elliott, 2004; Nagami o.fl., 2010; Rhoades og Eisenberger, 2002; Selvarajan o.fl., 2013; Willemse, Jonge, Smit, Depla og Pot, 2012) og miðað við niðurstöður rannsóknarinnar jafnframt á líðan peirra.

Upplifun á jákvæðum óyrtum samskiptum yfirmanna getur, miðað við niðurstöðurnar, dregið úr skynjun starfsfólks á tilfinningalegri vinnu. Pað er í samræmi við niðurstöður rannsóknar Jia o.fl. (2017). Mikil tilfinningaleg vinna starfsfólks getur krafist mikillar andlegrar orku (Grandey, 2000; Kruml og Geddes, 2000) sem getur leitt til streitu og óánægju (Kruml og Geddes, 2000; Jia o.fl., 2017; Nixon, 2009; Zapf, 2002; Pugh, Groth, og HennigThurau, 2011). Pví er ávinningur í pví fyrir bæði starfsfólk og ekki síður fyrirtæki í heild að reynt sé að draga úr tilfinningalegri vinnu með jákvæðum samskiptum.

Miðað við niðurstöður rannsóknarinnar er skynjun starfsfólks á tilfinningalegu gildi jákvæðara ef pað upplifir jákvæð óyrt samskipti frá yfirmanni sínum. Jákvætt tilfinningalegt gildi eykur líkur á starfsánægju og almennri jákvæðri hegðun í vinnunni (Brockner og Higgins, 2001). Pví er ástæða til og æskilegt að yfirmenn leggi sig fram um að hafa áhrif á pað í gegnum jákvæð óyrt samskipti.

Miðað við niðurstöður rannsóknarinnar eru pað fyrst og fremst óyrt samskipti sem fela í sér annars vegar andlitstjáningu og hins vegar líkamstjáningu sem skýra tilfinningalega líðan starfsfólks. Sé tekið mið af pessu ættu yfirmenn að leggja áherslu á að halda augnsambandi við starfsfólk sitt pegar samskipti eiga sér stað og sýna jákvæð svipbrigði eins og bros. Jafnframt ætti að leggja áherslu á afslappaða en líflega líkamsstöðu, t.d. með pví að nota hendurnar pegar talað er. Stór hluti óyrtrar hegðunar á sér stað ómeðvitað (Dimberg, Thunberg og Elmehed, 2000) og pví getur verið erfitt að stjórna henni (DePaulo 1992; Ekman og Friesen 1969, 1974). En í ljósi peirra áhrifa sem pessi tegund samskipta getur haft á starfsfólk er mikilvægt að yfirmenn hugi að og séu meðvitaðir um skilaboðin sem peir senda frá sér í gegnum andlitstjáningu og líkamlega tjáningu og að pau séu jákvæð. Sé pað gert er pað líklegt til að hafa jákvæð áhrif á tilfinningalega líðan starfsfólks og um leið jákvæð áhrif á rekstur fyrirtækisins.

Prátt fyrir að áreiðanleiki mælitækisins hafi reynst góður kann að vera ástæða til að í frekari rannsóknum verði hugað að próun á staðbundnu mælitæki par sem tekið er mið af peirri menningu sem ríkir. Merking og skilningur á óyrtum samskiptum getur verið ólíkur á milli menningarheima (Floyd, 2006) auk pess sem hegðun sem er viðeigandi á einum stað kann að pykja óviðeigandi annars staðar (Addis, 2008). Að auki er vert að hafa í huga að kynjaskipting í úrtakinu var nokkuð ójöfn prátt fyrir að lögð hafi verið áhersla á að reyna að jafna hlutfallið. Í frekari rannsóknum á efninu væri vert að leggja áherslu á jafnara hlutfall kynjanna og mögulega kanna hvort mögulega sé að finna kynjamun pegar kemur að upplifun á óyrtum samskiptum.

Раð kann að vera ákveðin takmörkun að í rannsókninni var ekki mæld eiginleg hegðun pegar kemur að óyrtum samskiptum heldur upplifun pátttakenda á óyrtri hegðun yfirmanns. Slíkt mat kann að vera skekkt og er hugsanlega ekki að mæla raunverulega óyrta hegðun yfirmanns. Á móti kemur að tilfinningar, og par með tilfinningaleg líðan eins og einblínt var á í rannsókninni, snúa fyrst og fremst að upplifun á tilteknum aðstæðum (Andersen, 1979) og eru viðbragð við peirri upplifun (Mottet, Frymier og Beebe, 2006; Parkinson, Totterdell, Briner og Reynolds, 1996). Раð er pví upplifun einstaklinga af aðstæðunum, par með upplifun starfsfólks af óyrtri hegðun yfirmanna, sem kallar fram tilteknar tilfinningar og tilfinningalega líðan. Engu að síður væri gagnlegt í frekari rannsóknum á efninu að mæla áhrif raunverulegrar óyrtrar hegðunar yfirmanna á starfsfólk, til að mynda með tilraunasniði.

Rannsóknin er mikilvægt framlag til stjórnunarfræðanna par sem skortur hefur verið á rannsóknun sem snúa að upplifun starfsfólks á óyrtri hegðun yfirmanna. Hagnýtt gildi 
rannsóknarinnar er ekki síður mikilvægt par sem niðurstöðurnar sýna fram á mikilvægi pess að yfirmenn séu meðvitaðir um pau skilaboð sem peir senda frá sér með óyrtum samskiptum, sér í lagi með andlitstjáningu og líkamlegri tjáningu.

\section{Heimildir}

Ambady, N. og Weisbuch, M. (2010). Nonverbal behavior. Í S. T. Fiske, D. T. Gilbert, G. Lindzey (ritstj.), Handbook of Social Psychology: 464-497. Hoboken, NJ: Wiley. doi:10.1002/9780470561119.socpsy001013

Andersen, J. F. (1979). Teacher immediacy as a predictor of teacher effectiveness. Communication Yearbook, 3, 543-559. doi:10.1080/23808985.1979.11923782

Arnold, K. A., Turner, N., Barling, J., Kelloway, E. K. og McKee, M. C. (2007). Transformational leadership and psychological well-being: the mediating role of meaningful work. Journal of Occupational Health Psychology, 12(3), 193-203.

Awamleh, R. og Gardner, W. L. (1999). Perceptions of leader charisma and effectiveness: The effects of vision content, delivery, and organizational performance. The Leadership Quarterly, 10(3), 345-373. doi:10.1016/ s1048-9843(99)00022-3

Beehr, T. A., Farmer, S. J., Glazer, S., Gudanowski, D. M. og Nair, V. N. (2003). The enigma of social support and occupational stress: Source congruence and gender role effects. Journal of occupational health psychology, 8(3), 220. doi:10.1037/1076-8998.8.3.220

Birdwhistell, R. (1970) Kinesics and context. University of Pennsylvania press, Philadelphia. doi:10.9783/9780812201284

Bonaccio, S., O'Reilly, J., O'Sullivan, S. L. og Chiocchio, F. (2016). Nonverbal behavior and communication in the workplace: A review and an agenda for research. Journal of Management,42(5), 1044-1074. doi: $10.1177 / 0149206315621146$

Brockner, J., \& Higgins, E. T. (2001). Regulatory focus theory: Implications for the study of emotions at work. Organizational behavior and human decision processes, 86(1), 35-66.

Burgoon, J. K., Blair, J. P. og Strom, R. E. (2008). Cognitive biases and nonverbal cue availability in detecting deception. Human Communication Research, 34(4), 572-599. doi:10.1111/j.1468-2958.2008.00333.x

Burgoon, J. K., Buller, D. B., og Woodall, W. G. (1996). Nonverbal communication: The unspoken dialogue. New York: McGraw-Hill.

Burgoon, J. K., Guerrero, L. K., og Manusov, V. (2011). Nonverbal signals. Í M. L.

Buzzanell, P. og Turner, L. (2003). Emotion work revealed by job loss discourse: Backgrounding- foregrounding of feelings, construction of normalcy, and (re)instituting of traditional masculinities. Journal of Applied Communication Research, 31, 27-57.

Casler, K., Bickel, L. og Hackett, E. (2013). Separate but equal? A comparison of participants and data gathered via Amazon's MTurk, social media, and face-to-face behavioral testing. Computers in human behavior, 29(6), 2156-2160.

Colquitt, J. A. og LePine, J. A. (2000). Towards an integrative theory of training motivation: A meta- analytic path analysis of 20 years of research. Journal of Applied Psychology, 85(5), 678-707.

Darioly, A. og Schmid Mast, M. S. (2014). The role of nonverbal behavior in leadership: An integrative review. Leader Interpersonal and Influence Skills: The Soft Skills of Leadership, 1771-2335. doi:10.4324/9780203760536

Decker, P. og Borgen, F. (1993). Dimensions of work appraisal: stress, strain, coping, job satisfaction, and negative affectivity. Journal of Counseling Psychology, 40, 470-478.

DePaulo, B. M. (1992). Nonverbal behavior and self-presentation. Psychological Bulletin, 111, 203-243.

Dimberg, U., Thunberg, M. og Elmehed, K. (2000). Unconscious Facial Reactions to Emotional Facial Expressions. Psychological Science, 11(1), 86-89. doi:10.1111/1467-9280.00221

Ekman, P. og Friesen, W. V. (1969). The repertoire of nonverbal behavior: Categories, origins, usage, and coding. Semiotica, 1 , 48-98.

Ekman, P. og Friesen, W. V. (1974). Detecting deception from the body or face. Journal of Personality and Social Psychology, 29, 288-298.

Field, A. (2005). Discorvering statistics using SPSS (3. útgáfa). London: Sage.

Fitness, J. (2000). Anger in the workplace: An emotion script approach to anger episodes between workers and their superiors, co-workers and subordinates. Journal of Organizational Behavior, 21, 147-162. doi:10.1002/ (sici)1099-1379(200003)21:2<147::aid-job35>3.0.co;2-t

Fox, S. og Stallworth, L. E. (2005). Racial/ethnic bullying: Exploring links between bullying and racism in the US workplace. Journal of Vocational Behavior, 66, 438- 456. doi:10.1016/j.jvb.2004.01.002

Frone, M. R. (2000). Interpersonal conflict at work and psychological outcomes: Testing a model among young workers. Journal of Occupational Health Psychology, 5, 246 -255. doi:10.1037//1076-8998.5.2.246

Fuller, B., Simmering, M. J., Marler, L. E., Cox, S. S., Bennett, R. J., \& Cheramie, R. A. (2011). Exploring touch as a positive workplace behavior. Human Relations, 64(2), 231-256.

Galletta, M., Portoghese, I., Penna, M. P., Battistelli, A., og Saiani, L. (2011). Turnover intention among Italian nurses: The moderating roles of supervisor support and organizational support. Nursing and Health Sciences, 13(2), 184-191. doi:10.1111/j.1442-2018.2011.00596.x 
Gardner, W.L. (2003), "Perceptions of leader charisma, effectiveness, and integrity effects of exemplification, delivery, and ethical reputation", Management Communication Quarterly,16(4), 502-527. doi: $10.1177 / 0893318903251324$

Gibson, J. A., Grey, I. M. og Hastings, R. P. (2009). Supervisor support as a predictor of burnout and therapeutic self-efficacy in therapists working in ABA schools. Journal of Autism and Developmental Disorders, 39(7), 1024-1030. doi:10.1007/s10803-009-0709-4

Gkorezis, P., Bellou, V. og Skemperis, N. (2015). Nonverbal communication and relational identification with the supervisor: Evidence from two countries. Management Decision, 53(5), 1005-1022. doi:10.1108/md-112014-0630

Gilbreath, B. og Benson, P. G. (2004). The contribution of supervisor behaviour to employee psychological well-being. Work og Stress, 18(3), 255-266. doi:10.1080/02678370412331317499

Gillard, S. og Johansen, J. (2004). Project management communication: A systems approach. Journal of Information Science, 30(1), 23-29.

Glomb, T. (2002). Workplace anger and aggression: Informing conceptual models with data from specific encounters. Journal of Occupational Health Psychology, 7(1), 20-36. doi:10.1037/1076-8998.7.1.20

Grandey, A. A. (2000). Emotional regulation in the workplace: A new way to conceptualize emotional labor. Journal of occupational health psychology, 5(1), 95. doi:10.1037/1076-8998.5.1.95

Grebner, S., Semmer, N. K., \& Elfering, A. (2005). Working conditions and three types of well-being: a longitudinal study with self-report and rating data. Journal of Occupational Health Psychology, 10(1), 31-43.

Hinkle, L. L. (2001). Perceptions of supervisor nonverbal immediacy, vocalics, and subordinate liking. Communication Research Reports, 18, 128-136. doi:10.1080/08824090109384790

Jenkins, R. og Elliott, P. (2004). Stressors, burnout and social support: Nurses in acute mental health settings. Journal of Advanced Nursing, 48(6), 622-631. doi:10.1111/j.1365-2648.2004.03240.x

Jia, M., Cheng, J. og Hale, C. L. (2017). Workplace emotion and communication: Supervisor nonverbal immediacy, employees' emotion experience, and their communication motives. Management Communication Quarterly, 31(1), 69-87. doi:10.1177/0893318916650519

Jia, M. Y. og Shoham, M. D. (2012). Communication motives, satisfaction, and social support in the workplace: Are supervisors effective support sources in employee networks? Í Proceedings of the Forty-Fifth Annual Hawaii International Conference on System Sciences. New Brunswick doi:10.1109/hicss.2012.164

Keyes, C. L., Shmotkin, D. og Ryff, C. D. (2002). Optimizing well-being: the empirical encounter of two traditions. Journal of personality and social psychology, 82(6), 1007-1022.

Kruml, S. og Geddes, D. (2000). Exploring the dimensions of emotional labor: The heart of Hochschild's work. Management Communication Quarterly, 14, 18-49. doi:10.1177/0893318900141002

Landy, F. og Conte, J. M. (2013). Work in the 21st century : An introduction to industrial and organizational psychology. (4. útg.). doi:10.1111/j.1744-6570.2008.00119_2.x

LeBlanc, M. M. og Kelloway, E. K. (2002). Predictors and outcomes of workplace violence and aggression. Journal of Applied Psychology, 87(3), 444-453. doi:10.1037/0021-9010.87.3.444

Marler, L., Cox, S., Simmering, M., Bennett, R. og Fuller, J. (2011). Exploring the Role of Touch and Apologies in Forgiveness of Workplace Offenses. Journal of Managerial Issues, 23(2), 144-163. doi:10.1177/0018726710377931

Miceli, M. (2009). The art of comforting. New Ideas in Psychology, 27, 343-361. doi:10.1016/j.newideapsych.2009.01.001

Miller, K. I. (2007). Compassionate communication in the workplace: Exploring the process of noticing, connecting, and responding. Journal of Applied Communication Research, 35, 223-245. doi:10.1080/00909880701434208

Miller, K. I. (2009). Organizational Communication: Approaches and Processes (5.útg.). Boston, MA: Wadsworth Cengage Learning. doi:10.1002/9781405186407.wbieco018

Moss, B. (2008) Communication skills for health and social care, London: Sage. doi:10.1093/bjsw/bcy058

Mottet, T., Frymier, A. og Beebe, S. (2006). Theorizing about instructional communication. Í T. Mottet, V. Richmond og J. McCroskey (Ritstj.), Handbook of instructional communication: Rhetorical and relational perspectives, 255-282. Boston, MA: Pearson Education. doi:10.4135/9781412976152.n22

Nagami, M., Tsutsumi, A., Tsuchiya, M. og Morimoto, K. (2010). Job control and coworker support improve employee job performance. Industrial Health, 48(6), 845-851. doi:10.2486/indhealth.ms1162

Nixon, D. (2009). 'I can't put a smiley face on': Working-class masculinity, emotional labour and service work in the 'New Economy.' Gender. Work E Organization, 16, 300-322. doi:10.1111/j.1468-0432.2009.00446.x

Nohe, C., Michaelis, B., Menges, J.I., Zhang, Z. og Sonntag, K. (2013), “Charisma and organizational change: a multilevel study of perceived charisma, commitment to change, and team performance", The Leadership Quarterly, 24( 2), 378-389. doi:10.1016/j.leaqua.2013.02.001

Parkinson, B., Totterdell, P., Briner, R.B. og Reynolds, S. (1996). Changing moods: The psychology of mood and mood regulation. London: Longman. doi:10.5860/choice.34-4770

Porter, S., Brinke, L. og Wallace, B. (2012). “Secrets and lies: Involuntary leakage in deceptive facial expressions as a function of emotional intensity". Journal of Nonverbal Behavior, 36(1), 23-37. doi:10.1007/s10919-0110120-7

Pugh, S. D., Groth, M. og Hennig-Thurau, T. (2011). Willing and able to fake emotions: A closer examination 
of the link between emotional dissonance and employee well-being. Journal of Applied Psychology, 96(2), 377-39doi:10.1037/a0021395

Rayner, C., Hoel, H. og Cooper, C. (2002). Workplace Bullying. London: CRC Press, doi:10.1201/b12811

Richmond, V. P., og McCroskey, J. C. (2000). The impact of supervisor and subordinate immediacy on relational and organizational outcomes. Communication monographs, 67, 85-95. doi:10.1080/03637750009376496

Richmond, V. P., McCroskey, J. C., og Johnson, A. D. (2003). Development of the nonverbal immediacy scale (NIS): Measures of self-and other-perceived nonverbal immediacy. Communication Quarterly, 51(4), 504517. doi:10.1080/01463370309370170

Rife, S. C., Cate, K. L., Kosinski, M., \& Stillwell, D. (2016). Participant recruitment and data collection through Facebook: The role of personality factors. International Journal of Social Research Methodology, 19(1), 69-83.

Riggio, R.E., Salinas, C., Riggio, H.R. og Cole, E.J. (2003), "The role of social and emotional communication skills in leader emergence and effectiveness", Group Dynamics: Theory, Research, and Practice,7(2), 83-103. doi:10.1037/1089-2699.7.2.83

Robertson, I.T. og Flint Taylor, J. (2008), "Leadership, psychological well-being and organizational outcomes", in Cartwright, S. and Cooper, C.L. (Ritstj.), Oxford Handbook on Organizational Well-being, Oxford University Press, Oxford. doi:10.1093/oxfordhb/9780199211913.003.0008

Rhoades, L. og Eisenberger, R. (2002). Perceived organizational support: a review of the literature. Journal of applied psychology, 87(4), 698.

Rugulies, R., Bültmann, U., Aust, B. og Burr, H. (2006). Psychosocial work environment and incidence of severe depressive symptoms: Prospective findings from a 5-year follow-up of the Danish Work Environment Cohort Study. American Journal of Epidemiology, 163(10), 877-887. doi:10.1093/aje/kwj119

Schimmack, U., Radhakrishnan, P., Oishi, S., Dzokoto, V., \& Ahadi, S. (2002). Culture, personality, and subjective well-being: Integrating process models of life satisfaction. Journal of personality and social psychology, 82(4), 582-593.

Selvarajan, T. T., Cloninger, P. A. og Singh, B.(2013). Social support and work-family conflict: A test of an indirect effects model. Journal of Vocational Behavior, 83(3), 486-499. doi:10.1016/j.jvb.2013.07.004

Sinokki, M., Hinkka, K., Ahola, K., Koskinen, S., Kivimäki, M., Honkonen, T., Puukka, P., Klaukka, T., Lönnqvist, J. og Virtanen, M. (2009). The association of social support at work and in private life with mental health and antidepressant use: The Health 2000 Study. Journal of Affective Disorders, 115(1-2), 36-45. doi:10.1016/j.jad.2008.07.009

Teven, J. J. (2007). Effects of supervisor social influence, nonverbal immediacy, and biological sex on subordinates' perceptions of job satisfaction, liking, and supervisor credibility. Communication Quarterly, 55(2), 155-177. The unspoken dialogue. New York: McGraw-Hill. doi:10.1080/01463370601036036

Teven, J. J. (2010). The Effects of supervisor nonverbal immediacy and power use on employees' ratings of credibility and affect for the supervisor. Human Communication, 13(2), 69-85. doi:10.1080/01463370601036036

Thornton, L., Batterham, P. J., Fassnacht, D. B., Kay-Lambkin, F., Calear, A. L. og Hunt, S. (2016). Recruiting for health, medical or psychosocial research using Facebook: Systematic review. Internet Interventions, 4, $72-81$.

Titsworth, S., McKenna, T., Mazer, J. P. og Quinlan, M. M. (2013). The bright side of emotion in the classroom: How teachers influence students' enjoyment, hope, and pride. Communication Education, 62, 191-209. doi: 10.1080/03634523.2013.763997

Titsworth, S., Quinlan, M. og Mazer, J. (2010). Students' emotional experiences in the classroom: the role of teachers' communication competence, immediacy, and clarity. Communication Education, 59, 431-452. doi:10.1080/03634521003746156

Willemse, B. M., de Jonge, J., Smit, D., Depla, M. F. I. A. og Pot, A. M. (2012). The moderating role of decision authority and coworker- and supervisor support on the impact of job demands in nursing homes: A crosssectional study. International Journal of Nursing Studies, 49(7), 822-833. doi:10.1016/j.ijnurstu.2012.02.003

Yukl, G. (2002). Leadership in Organizations, Prentice Hall, Upper Saddle River, NJ. doi:10.2307/257314

Zapf, D. (2002). Emotion work and psychological well-being: A review of the literature and some conceptual considerations. Human Resource Management Review, 12, 237-268. doi:10.1016/S1053-4822(02)00048-7 